See Article page 563.

\section{Commentary: Surgical reconstruction with the help of a 3-dimensional printer}

\author{
Charles Laurin, MD, and \\ Siamak Mohammadi, MD, FRCSC
}

The evolution of cardiothoracic surgery was made possible by of the actions of courageous surgeons who were keen to tackle complex challenges. In this issue of JTCVS Techniques, Tsai and colleagues ${ }^{1}$ report the successful and complete surgical treatment of a Floyd type I tracheal agenesis associated with a congenital valvular heart defect. It is the second report of esophagotracheoplasty using 3-dimensional (3D)-printed external support. ${ }^{2}$

The authors managed this rare case of tracheal reconstruction with a bioresorbable 3D-printed splint to substitute the trachea and to externally support their esophagotracheoplasty. The authors were later able to perform a right colon interposition to restore the gastrointestinal continuity. At more than 36 months of life, the child is alive, has resumed oral nutrition, and has achieved the motor development milestones of a 1-year-old.

The novelty of this approach goes beyond the interests of a handful of specialized pediatric and thoracic surgeons. These customized prostheses are particularly enticing for the younger patient population, where ongoing growth is a major drawback to any permanent reconstruction. ${ }^{3}$ Bioresorbable implants also have the potential advantages to decrease the amount of postoperative fibrosis and erosion into surrounding tissues, lowering the risk of future surgery.

Tsai and colleagues ${ }^{1}$ are to be praised for sharing their strategy for the complex treatment of tracheal agenesis

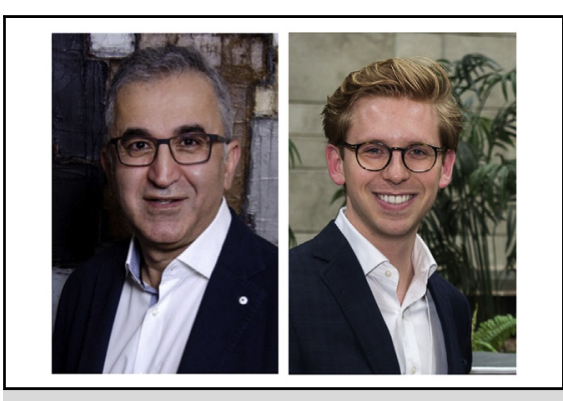

Siamak Mohammadi, MD, FRCSC, and Charles Laurin, MD

\section{CENTRAL MESSAGE \\ A bioresorbable 3D-printed external splint could be a viable solution for rare, lethal airway agenesis.}

with a bioresorbable splint, with a clear description of surgical steps. Despite the rarity of this congenital condition, the technology could be applied to other pediatric and adult thoracic pathologies requiring temporary internal or external splinting.

\section{References}

1. Tsai AY, Moroi MK, Les AS, Hollister SJ, Green GE, Cilley RE, et al. Trachea agenesis: esophageal airway support with a 3-dimensional-printed bioresorbable splint. J Thorac Cardiovasc Surg Tech. 2021;10:563-8.

2. Beste DJ, Amos LB, Lang CA, Woods RK, Kouretas PC, Mitchell ME. Neonatal esophageal trachealization and esophagocarinoplasty in the treatment of flowlimited Floyd II tracheal agenesis. J Thorac Cardiovasc Surg. 2017;153:e121-5.

3. Kamran A, Smithers CJ, Baird CW, Jennings RW. Experience with bioresorbable splints for treatment of airway collapse in a pediatric population. J Thorac Cardiovasc Surg Tech. 2021;8:160-9.

\footnotetext{
From the Department of Cardiac Surgery, Quebec Heart and Lung Institute, Quebec City, Quebec, Canada.

Disclosures: The authors reported no conflicts of interest.

The Journal policy requires editors and reviewers to disclose conflicts of interest and to decline handling or reviewing manuscripts for which they may have a conflict of interest. The editors and reviewers of this article have no conflicts of interest.

Received for publication Sept 6, 2021; revisions received Sept 6, 2021; accepted for publication Sept 10, 2021; available ahead of print Sept 16, 2021.

Address for reprints: Siamak Mohammadi, MD, FRCSC, Department of Cardiac Surgery, Quebec Heart and Lung Institute, 2725 chemin Sainte-Foy, Quebec City, Quebec, Canada G1V 4G5 (E-mail: siamak.mohammadi@fmed.ulaval.ca).

JTCVS Techniques 2021;10:571

2666-2507

Copyright (C) 2021 The Author(s). Published by Elsevier Inc. on behalf of The American Association for Thoracic Surgery. This is an open access article under the CC BY license (http://creativecommons.org/licenses/by/4.0/).

https://doi.org/10.1016/j.xjtc.2021.09.026
} 